Review

\title{
Demographics and the social reckoning in the Arab region
}

N.M. Kronfol

$$
\text { نبيل قرنفل الديموغرافية والاعتبارات الاجتماعية في البلدان العربية }
$$

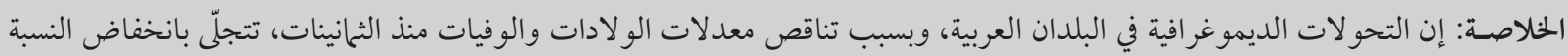

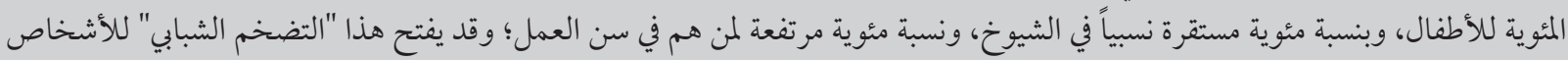

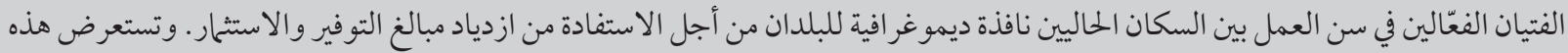

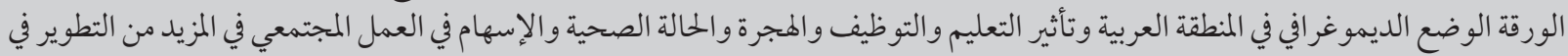

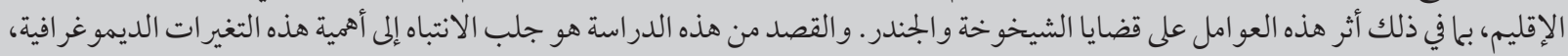

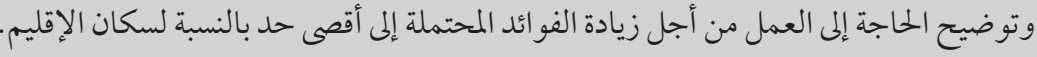

ABSTRACT Demographic transitions in the Arab countries, due to declining birth rates and mortality rates since the 1980s, are reflected in a low proportion of children, a relatively stable proportion of elderly and a high proportion of people of working age. This "youth bulge" of young, active, working-age individuals in the current population may open a demographic window for countries to benefit from increased savings and investment. This paper reviews the demographic situation in the Arab region and the impact of education, employment, migration, health status and participation in society on the further development of the region, including the impact of these factors on ageing and gender issues. The intent is to draw attention to the importance of these demographic changes and highlight the need for action to maximize the potential benefit to the population in this region.

\section{Démographie et reconnaissance sociale dans la Région arabe}

RÉSUMÉ Les transitions démographiques dans les pays arabes, en raison de la baisse des taux de natalité et de mortalité depuis les années 1980, se traduisent par une proportion plus faible d'enfants, une proportion relativement stable de la population âgée et une proportion élevée de personnes en âge de travailler. Cet excédent démographique de personnes jeunes, actives, en âge de travailler dans la population actuelle pourrait permettre aux pays de profiter d'une hausse de l'épargne et de l'investissement. Le présent article examine la situation démographique dans la Région arabe et l'impact du niveau d'études, de l'emploi, de la migration, de l'état de santé et de la participation dans la société sur le développement à venir de la Région, notamment l'impact de ces facteurs sur le vieillissement de la population et les questions liées aux spécificités hommefemme. L'objectif est d'attirer l'attention sur l'importance de ces changements démographiques et de souligner la nécessité d'intervenir afin de maximiser les bénéfices potentiels pour la population dans cette Région. 


\section{Introduction}

Understanding the effect of population change on economic growth and development is taking on added importance in the Arab region. Demographic transition produces a "boom" generation that may provide an opportunity to unleash an economic growth spurt [1]. Because birth rates in Arab countries remained high until the 1980s and then declined sharply, the proportion of young, active, working-age individuals in the current population is exceptionally large. Young people entering the labour market today do not have to mortgage the future benefits of their work to support either numerous children (as happened in the recent past) or the elderly (as will occur in the near future). The United Nations Population Division has defined the demographic dividend as the period when the proportion of children aged < 15 year falls below $30 \%$ and the proportion of old people $65+$ years is still below $15 \%$ [2]. This situation, favourable to savings and investment, can theoretically yield a dividend, a "demographic gift”, for the entire population. To seize this opportunity, critical policy areas need to be addressed. Policy-makers must plan for the future health care and pension income needs of this babyboom generation when it ages.

This is a review of the demographic situation in the Arab region and the impact of education, employment, migration, health status and participation in society on the further development of the region, including the impact of these factors on ageing and gender issues. This review draws on published reports and studies by individual researchers and those in international organizations. No new data or findings are presented. The intent is to draw attention to the importance of these demographic changes and highlight the need for action to maximize the potential benefit to the population in this region.

\section{Demography}

The population of the Arab countries has increased between 1980 and 2010, rising from 170 million (3.8\% of the total world population) to roughly 366 million in 2010 (about $6 \%$ of the world population) [2]. The rate of expansion has been most dramatic in the Gulf Cooperation Council (GCC) states, where the number of residents has increased nearly 7-fold since 1960 [3] due to the region's unique migration patterns and high fertility rates [4].

The annual population growth in the Middle East and North Africa reached a peak of 3\% in around 1980 ( $2 \%$ in the world) but is predicted to decline to $2.0 \%$ ( $1.2 \%$ in the world [5]) between 2000 and 2020. In spite of this reduction, the population of the Arab countries is expected to continue to grow for several more decades. The Arab countries are therefore experiencing an unprecedented "youth bulge" with over $30 \%$ of the population now in the age group 15-29years, representing over 100 million people [6]. Most Arab countries have also experienced large growths in their urban populations (Table 1), as people from rural areas gravitated towards urban employment.

\section{Definition of youth}

The United Nations defines youth as the age range 15-24 years, although others have defined this differently, including a range as wide as $10-35$ years [7]. Youth is a very important phase in the human life cycle. Economically, youth are in transition from economic dependency to economic productivity. In terms of family formation, youth are often at the stage of identifying a partner for marriage, childbearing and establishment of an autonomous family. Mostly, youth is the stage of personality formation and self-realization.

Despite major improvements in health and education over recent decades, and despite a wealth of oil resources, the "[Middle East and North Africa's] political, social, and economic systems have not evolved in a way that effectively meets the changing needs of its rapidly growing young population, especially employment" [6]. The extent to which this large group of young people will become productive members of their societies depends on how well governments and civil societies invest in the social, economic and political institutions that meet the current needs of young people. Political participation and civic engagement are other

\begin{tabular}{|c|c|c|c|}
\hline Field of study & $\begin{array}{l}\text { Middle East } \\
\text { graduates }^{\mathrm{a}}\end{array}$ & Asian graduates $^{\mathbf{b}}$ & $\begin{array}{l}\text { Latin American } \\
\text { graduates }^{c}\end{array}$ \\
\hline Education and Humanities & 37 & 20 & 9 \\
\hline Social Sciences & 31 & 34 & 39 \\
\hline Medicine & 6 & 6 & 11 \\
\hline Scientific, Technical and Engineering & 18 & 31 & 24 \\
\hline Other & 8 & 10 & 9 \\
\hline
\end{tabular}

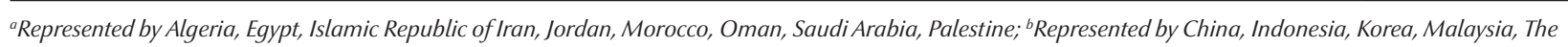
Philippines, Thailand; 'Represented by Argentina, Bolivia, Brazil, Chile, Columbia, Mexico, Peru. Source: World Bank [14]. 
important means of providing the youth populations in the region with the tools they need to build successful futures. Civil society organizations can play an important role in this domain.

\section{Fertility}

Although the mortality rate in the countries of the Arab region began to decline in the late 19th and early 20th centuries, the decline in fertility (births per woman) did not start until the 1970s. On average, fertility in the Arab countries has declined from 7 children per woman around 1960 to 3.6 in 2000 [8]. Coupled with a significant decline in child mortality, this led to an increase in the proportion of children under 15 years, and then to an increase in the proportion of young people aged $15-24$ years. The youth bulge is more pronounced in countries where the onset of fertility decline occurred later and the decline was steeper.

During the 1980s, policy-makers attempted to curb runaway population growth by encouraging birth control and promoting family planning programmes which were effective in stabilizing, and even decreasing, the fertility rate. This decline in fertility is attributable to a variety of correlated factors including better levels of education, particularly among women, women's relatively higher participation in the labour force, later marriages and increased contraceptive prevalence rates [2]. The decline in fertility rates in the Arab countries is predicted to continue in the coming decades, yet with variable speed from one country to another:

- Tunisia, Lebanon, Bahrain, Algeria, United Arab Emirates, Kuwait have reached or will reach replacement level (i.e. total fertility rate of 2.1 children/woman) before 2020 .

- Libya, Qatar, Morocco will reach replacement level between 2020-2030.
- Jordan, Syrian Arab Republic, Egypt will reach replacement level between 2030-2040.

- Comoros, Djibouti, Sudan, Somalia, Iraq, Oman, Palestine, Mauritania, Yemen will reach replacement level after 2040.

However, until at least 2030, the generation reaching working age will be much larger than that reaching retirement age. Therefore, the size of the total working-age population will continue to rise steeply during the next 2 decades.

\section{Ageing and the older population}

Along with the demographic changes noted above, the Arab region will witness the gradual (and fast) increase of its older population (aged 65+ years). Whereas the proportion of older people is still in the range of $1 \%-4 \%$ in most countries of the region, Lebanon and Tunisia already report that the old constitute more than $7 \%$ of their respective population $[9,10]$. Therefore governments ought to plan for the needs of the older population, including better access to health care, social protection and pension plans especially for older women. Legislation for pension reforms have already been enacted in several Arab states. Much of the care required by the elderly in the Arab region is currently provided by family caregivers. However, this is likely to change as due to social trends and population migration an increasing share of older people are likely to be living apart from their families. Providing social and health care for the elderly will be a major challenge in the region in years to come.

\section{Education}

Education is a fundamental human right. Over the last 2 decades, Arab countries have achieved remarkable progress in educational indicators. The average rate of inclusion in primary education has increased to $80.6 \%$, while the proportion of literate young people between 15-24 years of age has reached $83.4 \%$. Moreover, the gender parity index for literacy became 0.92 in 2005. The region's investment in female education in the past few decades has been impressive and most countries have nearly closed the gender gap on youth literacy [11]. However, despite this progress, the goal of universal education has not been achieved [12], nor has the standard of achievement been uniform across subregions and countries in the Arab region.

Participation in secondary and university education still needs to be improved in the Arab countries [13]. Higher education tends to focus on academic disciplines that are often incompatible with the needs of the labour market. The percentage of students enrolled in scientific disciplines such as natural sciences does not exceed $30 \%$ of overall university enrolment [6]. Arab youth may find themselves having to reconsider their acquired skills, and make efforts to acquire new skills, especially in information and communications technology. Moreover, the region is still unable to bridge the educational gaps between rich and poor and between urban and rural areas, especially for women. Poverty, early marriage, lack of female teachers and girls' schools and general security conditions and civic strife are the major impediments.

Education in the Arab region suffers quantitative and qualitative deficiencies. The sector suffers from deficiencies in the curriculum and educational infrastructure, especially in public schools. Despite the increase in private universities over the last decade, there are indications that educational opportunities (when available), are often of low quality due to overcrowding of classrooms, poor infrastructure, lack of teaching materials and a shortage of teachers and well-trained staff [14] Access to university is highly dependent on passing 
national tests which are designed primarily to measure the acquisition of facts and knowledge through rote learning rather than critical and independent thinking. Women continue to enrol in fields that are traditionally considered to be appropriate for women, such as education, humanities and the arts.

\section{Work and employment}

Employment is an important phase in the life cycle of youth, enabling them to achieve economic independence and the transition from dependence on family to self-reliance. Providing decent work opportunities for young people requires coherent social, economic and population policies. Tapping the full potential of youth is one of the most critical economic development challenges facing the Middle East in the 21 st century. The time spent between the end of education and obtaining their first job is often measured in years rather than months. A large majority of youth continue to live with their parents until well into their 20s. The combination of demographic pressures and social norms has creates what has been dubbed "waithood" — the long phase in which a large proportion of Middle Eastern youth spend waiting for employment and marriage [15].

Although unemployment rates vary from one country to another, on average more than $25 \%$ of youth in the Arab region are unemployed, the highest rate in the world. Youth unemployment in 2006 was reported to be $6.3 \%$ in the United Arab Emirates, $15.7 \%$ in Morocco, 17.0\% in Qatar, 18.7\% in Yemen, 19.7\% in Oman, 21.3\% in Lebanon, 25.8\% in Egypt and 38.9\% in Jordan [16]. This is likely to worsen; according to a World Bank report, the labour force of the Middle East and North Africa is expected to increase by $40 \%$ between 2000 and 2010, and by nearly 80\% between 2000 and 2020 [17]. Youth unemployment rates are especially high in countries that suffer from occupation and conflict; in Iraq the unemployment rate among young people was estimated at $27 \%$ in 2004 and $17.5 \%$ in 2006; and in Palestine at approximately $29.8 \%$ in 2006 and $28 \%$ in $2008[17,18]$.

Arab women still face barriers to employment. While women's participation in the labour force in the region reached $32 \%$ in 2006, it remained the lowest in the world (the world average was 58\%); men's labour force participation, on the other hand, is comparable to other regions of the world. There are great variations within the region in terms of women's participation in the economy and the extent to which it has changed and the recent drop in birth rates and the expanded education opportunities for women [19] mean that women are becoming more likely to delay marriage and join the workforce instead. It is also worth noting that the actual rates may also be substantially higher as many women work in the informal sector. Care work is neither valued as a contribution to development, nor distributed equally, and limits the opportunities available to women to pursue education and engage in income-generating employment.

Women in Arab countries work predominantly in the public sector (mostly in the education and health sectors); 49\% of women's employment is in services, compared with 39\% in agriculture and $12 \%$ in industry [20]. There are several reasons for the failure of private firms in the Arab region to employ young women, including labour markets highly segregated along gender lines; employers unwilling to assume the added cost of maternity leave and child care; women's limited geographic mobility; and the lack of labour-intensive, export-oriented industries that might otherwise employ women [21]. Nevertheless, the proportion of women who are wage and salaried workers has increased substantially [20]. This increased female economic activity is due mainly to higher levels of education and a rise in the average age for marriage. More women in the $30+$ years age group remain in the labour market, even after they are married and have children. This trend suggests that one income no longer suffices for the changing needs of the family and that attitudes toward women's work outside the home are slowly changing.

Promoting women's entrepreneurship is an effective way to address female unemployment and to help enhance women's economic empowerment.Arecent study showed that women account for only $13 \%$ of company owners in the Middle East region, compared with 24\% in Europe [19]. Women-owned firms are more likely to hire women. An issue that also deserves more attention is discouragement; when a person feels that a job search is a futile effort. It is very likely that discouragement among women is higher than among men.

Unemployment in Arab countries is concentrated among secondary-school and university graduates, rather than primary-school graduates and the illiterate (World Bank) [22]. This situation is caused by the gap between labour market requirements and educational outputs. University students are the fastest-growing group among new entrants to the labour market and the group most dependent on government employment, which is not growing fast besought or may even be shrinking [23]. Even for the most educated workers, a World Bank analysis suggests that the private sector in the Middle East and North Africa rewards education less than the public sector [17].

Added to the existing problems of youth unemployment, the workforce is expanding at a rate more than 3\% per year, which means that the region will require the creation of 100 million jobs in the next 20 years. The Arab region needs $6 \%-7 \%$ sustained economic growth in order to keep up with its growing population. In a recent report, the director general of the Arab Labour Organization noted that Arab countries will need to spend US\$ 85 billion over the next 
10 years in order to create new jobs and address an unemployment crisis [24].

Governments in the region have not focused their education policies on how to ensure that the region's young people have the right skills for the jobs being created. There is even less focus on how to encourage the private sector to play a role in addressing the region's pressing employment needs. Surveys of private employers in the region report that only one-third of new graduate employees are ready for the workplace when hired (Table2) [25]. Despite these challenges, the United Nations Development Programme concludes that education has boosted human capital in the region [26]. The oil-rich, labour-receiving Gulf countries are faced with the additional challenge of addressing the employment balance between their national and nonnational work force. A rapidly growing number of young nationals are entering the labour force at a time when their governments are no longer able to guarantee lifetime employment in the public sector, on which citizens have customarily relied. Nearly all of the Gulf states are now instituting policies that push the private sector to hire more nationals.

The social and political turmoil in the region has given renewed urgency to the need to counter chronic joblessness, particularly among young people [27]. In its report, Unlocking the employment potential in the Middle East and North Africa: toward a new social contract, the World Bank argues that countries of the region must adopt new development policies that realign their economies [17].

\section{Migration}

Statistics on international migration in the Arab region remain scarce. Political instability and armed conflict, along with unemployment and underemployment, have been major push factors behind population movements within and from the region. All Arab countries, except for the GCC countries and Libya, have become both origin and destination countries for migrants. In certain member countries, refugees still form a large proportion of the migrants [28]. Morocco and Egypt have become unwilling recipients of migrants from elsewhere, even while their own nationals form a major part of the migrant workforce elsewhere [29].

After slowing down in the 1990s, emigration from Arab countries regained momentum in the early part of this decade $[6,30]$. The 20 million migrants from Arab countries represent about $5 \%$ of the region's total population $[6,30]$. The region is home to several economies that benefit from or even depend on remittances from abroad, such as Egypt, Jordan, Lebanon, Morocco and Tunisia, as well as countries that are among the largest sources of remittances worldwide, such as Saudi Arabia, the United Arab Emirates, Qatar and Kuwait [31]. Remittances from migrant workers to Middle East and North
African countries reached US\$ 28.5 billion in 2007 according to the World Bank [32] and form one of the least volatile sources of foreign exchange earnings for developing countries [33].

\section{Health}

The health of youth in the Arab region has improved over past decades. Overall death rates have dropped in all Arab countries and are expected to decline more in the next 2 decades [34]. However, youth lifestyles, such as not exercising regularly, fastfood diets and smoking, are exposing them to numerous health hazards. There is an increase in the reported incidence of HIV/AIDS [35], although official figures may be underestimates. On the other hand, progress has been made in reproductive health, with the rates of unwanted childbirth and maternal mortality declining among young women, and the number of young people having comprehensive, accurate knowledge of how to avoid sexually transmitted diseases increasing considerably [35]. Fertility rates among adolescent women (ages 15-19 years) in the region have decreased [15] and the contraceptive prevalence rate (percentage of women ages $15-49$ years using contraceptives) has increased in all Arab countries [19].

There are still many problems to be tackled in women's health. Women with lower education levels are still marrying young and having high numbers of

Table 2 Survey of employers in the Arab region: responses to question about whether graduates hired in the last 5 years have appropriate skills

\begin{tabular}{lcccc}
\hline Country & $\begin{array}{c}\text { University graduates, } \\
\text { hard skills }\end{array}$ & $\begin{array}{c}\text { University graduates, } \\
\text { soft skills }\end{array}$ & $\begin{array}{c}\text { Vocational graduates, } \\
\text { hard skills }\end{array}$ & $\begin{array}{c}\text { Vocational graduates, } \\
\text { soft skills }\end{array}$ \\
Egypt & 29 & 26 & 16 & 12 \\
Jordan & 22 & 25 & 10 & 16 \\
Morocco & 33 & 28 & 36 & 25 \\
Saudi Arabia & 51 & 45 & 41 & 38 \\
Yemen & 29 & 26 & 23 & 19 \\
\hline
\end{tabular}

Source [25]. 
children, thus reinforcing the cycle of poverty [36]. There are wide urban-rural gaps in women's access to health services [36]. Female circumcision remains high in countries where it is traditionally practised (Djibouti, Sudan, Egypt, and in Yemen), even when the practice is illegal [37]. Violence against women, including honour killings persists [38], Honour killings have not been considered homicide and therefore not punished as such. There is also a high prevalence of domestic violence and sexual harassment in the Arab region [39].

\section{Participation in public life}

It is self-evident that youth who have the opportunity to participate in the life of their communities have a better chance of successful transition to adulthood, as such activities promote social integration. Nevertheless, there are still obstacles to full participation of youth in society especially in the Arab region. A United Nations report showed that Arab youth are not being represented in Arab legislatures or parliaments [40]. Moreover, Arab parliaments do not have separate committees for youth issues; instead, these are dealt with by committees concerned with sport, culture or family affairs. Older people control the process and mechanisms of youth participation in those societies. Young people are averse to political participation as they lack confidence in its procedures and the outcomes [7].

On the other hand, the region has witnessed some encouraging developments in the area of women's public participation and representation, even though the regional average is still the lowest in the world [19]. Some countries have been able to increase female representation in parliament, mainly through the use of quotas and appointments. Women candidates are generally more successful in local and municipal elections.

The feminization of poverty in the Arab region is reflected in the increasing number of poor households headed by women and a lack of adequate social welfare systems [19]. Gender inequality contributes to making women vulnerable to poverty. Women also face discrimination in property and inheritance rights [19].

\section{Conclusion}

Arab countries have diverse economies and their populations are at different stages of the transition from high to low fertility. Thus, their governments may choose different approaches to improve educational and job opportunities for youth. However, none can succeed in strengthening human capacity among youth without fundamental reforms and a greater engagement of civil society.

The labour market prospects of the region largely depend on how successfully its governments can develop new social contracts for the 21 st century. The extent to which this large group of young people will become healthy and productive members of their societies depends on how well governments and civil societies invest in social, economic, and political institutions that meet the current needs of young people. The recent social and political turmoil in the Arab countries has given renewed urgency to the need to counter chronic joblessness, particularly among young people. Governments can implement a number of immediate measures to step up job creation and enhance the employability of their young populations [27]. Policy should aim at relaxing rigid labour market regulations and at providing effective social protection. Nations undergoing the demographic transition have an opportunity to capitalize on the demographic dividend offered by the maturing of boom-era populations. Given the right kind of policy environment, this demographic dividend can help to produce a sustained period of economic growth [1].

I will end this review by quoting this declaration by Her Majesty Queen Rania Al Abdullah of Jordan [41]:

I was once told that the only way to predict the future is to have power to shape the future. Well, here in the Arab world, we have the power. The power is our youth. We have been blessed with the biggest youth population in the world; $60 \%$ of our region is under the age of thirty. If we could channel their energy... if we could harness their potential... we could change the fortunes of our region. With almost one quarter of our young people unemployed and losing hope every day, creating opportunity has never been so urgent. But right now, we are letting them down.

We are letting them down in illequipped classrooms with untrained teachers; we are letting them down with outmoded curriculums already obsolete in the modern marketplace; we are letting them down when they seek our advice and practical measures; and we are letting them down when we fail to expose them, at an early age, to the entrepreneurial spirit and potential of the private sector. From government to education providers to employers to civil society and to youth themselves, shaping our future is everyone's responsibility. If we can provide quality education that leads to lasting employment, we will have done our part in shaping the future of the Arab world. No one said it would be easy, but it is a regional imperative.

\section{References}

1. Bloom DE, Canning D, Sevilla J. The demographic dividend: a new perspective on the economic consequences of population change. Santa Monica, California, RAND Corporation, 2003.
2. World population prospects: the 2008 revision. New York, United Nations Population Division, 2008.

3. Goals and targets for monitoring the progress of youth in the global economy, Report of the Secretary General, addendum. 
New York, United Nations, General Assembly, Economic and Social Council, 2007 (A/62/61/Add.1-E/2007/7/ Add.1).

4. Khalifa AM. Youth bulge and the demographic window of opportunity in the Arab world. Paper presented at the United Nations Economic and Social Commission for Western Asia Expert Group Meeting on Moving the Development Agenda Forward: opportunities and potential gains, Beirut, 5-6 November 2009. Beirut, ESCWA, 2009.

5. Roudi F. Population trends and challenges in the Middle East and North Africa. Washington DC, Population Reference Bureau, 2001.

6. Assaad R, Roudi-Fahimi F. Youth in the Middle East and North Africa: demographic opportunity or challenge? Washington DC, Population Reference Bureau, 2007.

7. Youth in the ESCWA region: situation analysis and implications for development policies. Beirut, United Nations Economic and Social Commission for Western Asia, 2010 (ESCWA Population and Development Report 4th issue).

8. World population to 2300. New York, United Nations Department of Economic and Social Affairs, Population Division (ST/ ESA/SER.A/236), 2004.

9. Ben Brahim A. [Transition des structures par âge et vieillissement en Tunisie. Seminaires du CICRED]. Paris Cedex, Committee for International Cooperation in National Research in Demography, 2005.

10. Sibai A, Kronfol N. CSA country profile. Older population in Lebanon: facts and prospects. Beirut, Center for Studies on Aging/ United Nations Population Fund, 2011.

11. Gender and education for all. The leap to equality. Paris, United Nations Educational, Scientific and Cultural Organization Education, 2003/4.

12. Doing business 2008. Washington DC, World Bank, 2007.

13. Najib K. Development of Arab education systems to empower youth: challenges and future prospects. Series of Population and Development Studies. Cairo, Secretariat-General of the League of Arab States, Department of Population and Migration Policies, 2005 [in Arabic].

14. Education statistics (edstats). World Bank [online database] (http://web.worldbank.org/WBsite/External/Topics/Exteducation/Extdatastatistics/Extedstats/0,menuPK:3232818 pag ePK:64168427 piPK:64168435 theSitePK:3232764,00.html, accessed 10 February 2013).

15. Salehi-Isfahani D, Dhillon N. Stalled youth transitions in the Middle East: a framework for policy reform. Washington DC, Wolfensohn Center for Development/ Dubai School of Government, 2008 (Middle East Youth Initiative Working Paper No. 8).

16. Chaaban J. Job creation in the Arab economies: navigating through difficult waters. Arab Human Development Report Research Paper Series. New York, United Nations Development Programme, 2010.

17. Unlocking the employment potential in the Middle East and North Africa. Washington DC, World Bank, 2007.

18. Report on the impact of conflict and political crisis on the socioeconomic conditions of countries in Western Asia. Beirut, United Nations Economic and Social Commission for Western Asia, 2007.

19. The status and progress of women in the Middle East and North Africa. Washington DC, World Bank, 2007.

20. Global employment trends for women. Geneva, International Labour Organization, 2007.

21. The road not travelled: education reform in the Middle East and North Africa. Washington DC, World Bank, 2008.

22. World development report 2006: equity and development. Washington DC, World Bank, 2006.
23. Assaad R. Unemployment and youth insertion in the labor market in Egypt. Cairo, Egyptian Center for Economic Studies, 2007 (ECES Working Paper No. 118).

24. مطالب بتوفير 85 مليار دولار لمواجهة أزمة البطالة العربية. [Demands for provision of \$ 85 billion to address the Arab unemployment crisis.] AlJazeera [online] (http://www.al-jazirah.com/20110521/ec2d. $\mathrm{htm}$, accessed 10 February 2013).

25. Education for employment: realizing Arab youth potential. Washington DC, World Bank International Finance Corporation and the Islamic Development Bank, 2011.

26. Arab human development report 2003: building a knowledge society. New York, United Nations Development Programme, 2003.

27. Masood A. Creating jobs in the Middle East and North Africa. A commentary by Masood Ahmed, Director, Middle East and Central Asia Department, International Monetary Fund. Published in Asharg Al Awsat, 20 May 2011. Interntatonal Monetary Fund [online] (http://www.imf.org/external/np/vc/2011/052011. $\mathrm{htm}$, accessed 10 February 2013).

28. The state of the world's refugees. Geneva, United Nations High Commission for Refugees, 2006.

29. Fargues P. Emerging demographic patterns across the Mediterranean and their implications for migration through 2030. Washington D, Migration Policy Institute, 2008.

30. Fargues P. International migration in the Arab region: trends and policies. Paper presented at the United Nations Expert Group Meeting on International Migration and Development in the Arab Region, Beirut, May 2006.

31. Ghobril N. The global crisis and expatriates remittances to Lebanon. Chapter 31. In: Sirkeci I, Cohen JH, Ratha D, eds. Migration and remittances during the global financial crisis and beyond. Washington DC, World Bank, 2012.

32. Sirkeci I, Cohen JH, Ratha D, eds. Migration and remittances during the global financial crisis and beyond. Washington DC, World Bank, 2012.

33. Ratha D. Workers' remittances: an important and stable source of external finance. Washington DC, World Bank, 2003.

34. Sibai A, Kronfol N. Situation analysis of population ageing in the Arab countries: the way forward towards implementation of MI$P A A$. Beirut, United Nations Economic and Social Commission for Western Asia, 2008.

35. Youth in the ESCWA region: situation analysis and implications for development policies. Beirut, United Nations Economic and Social Commission for Western Asia, 2009 (Population and Development Report No. 4).

36. World DataBank. World Bank [online database] (http://databank.worldbank.org/data/home.aspx, accessed 10 February 2013).

37. Maternal mortality in 2005. Estimates developed by WHO, UNICEF, UNFPA and the World Bank. Geneva, World Health Organization/United Nations Children's Fund/ United Nations Population Fund/World Bank, 2007.

38. Marriage in the Arab world. Washington DC, Population Reference Bureau, 2005.

39. Gender and development in the Middle East and North Africa: women in the public sphere. Washington DC, World Bank, 2004.

40. Arab youth strategizing for the MDGs. New York, United Nations Development Programme/United Nations Department of Economic and Social Affairs, 2006.

41. Al Abdullah R. Reflections by the Chairperson. In: Education for employment: realizing Arab youth potential. Washington DC, World Bank International Finance Corporation and the Islamic Development Bank, 2011. 